\title{
European Union's Solidarity, Unity in Diversity and Free Movement in the Coronavirus Crisis
}

\author{
Koronavirüs Krizinde Avrupa Birliği’nin Dayanışma, Çeşitlilik içinde Birlik ve Serbest Dolaşımı \\ Neriman HOCAOĞLU BAHADIR ${ }^{\mathrm{a} *}$
}

${ }^{a}$ Dr. Öğr. Üyesi, Kırklareli Üniversitesi, Uluslararası İlişkiler Bölümü, Kırklareli / TÜRKIYE

ORCID: 0000-0002-3723-5554

\section{A K A LE B İL Gİ İ}

Makale Geçmişi:

Başvuru tarihi: 24 Ağustos 2020

Kabul tarihi: 23 Ekim 2020

Anahtar Kelimeler:

Avrupa Birliği,

Dayanışma,

Çeşitlilik içinde birlik,

Serbest dolaşım,

Koronavirüs krizi

\section{ARTICLE INFO}

Article History:

Received August 24, 2020

Accepted October 23, 2020

Keywords:

European Union,

Solidarity,

Unity in diversity,

Free movement,

Coronavirus crisis

\section{ÖZ}

AB II. Dünya Savaşı'ndan sonra yaşlı ve bitkin kıtaya barış, istikrar ve refahı getirip sürdürerek birçok şey başard. $\mathrm{AB}$ bunu ilk önce ekonomik iş birliği ile başlayarak başardı ancak zamanla üye ülkelerin siyasi ve sosyal yașamlarına nüfuz ederek genisledi ve derinlesti. Ancak kurulusundan beri AB'nin varlığı krizlerle sınanmıştır ve AB krizleri atlatmıştır. 2000'li yılların başından bu yana $\mathrm{AB}$, anayasal kriz, ekonomik kriz, göç krizi, Brexit ve şimdi de koronavirüs krizi gibi birçok kriz yaşadı. Değerleri ve başarılarının unsurları olan "dayanıșma", "çeșitlilik içinde birlik" ve "serbest dolașım" kavramları da sınandı ve sorgulandı. Bu araştırmada koronavirüs krizinin $\mathrm{AB}$ 'nin değerlerini ve başardıklarını nasıl etkilediği sorgulanmaktadır. $\mathrm{Bu}$ kriz AB'nin kendisi ve değerleri için bir varoluş savașı olabilir. Devletlerin bu krizde büyük bir darbe alacakları açıktır ancak AB, daha fazlasıyla karşılaşacaktır. Kriz bittiğinde ne olacağını görmek kolay olmasa da pek çok şeyin değişeceği açıktır.

\begin{abstract}
A B S T R A C T
The EU succeeded many things by bringing and sustaining peace, stability and prosperity to the old and exhausted continent after the II. World War. The EU achieved this by first starting with economic collaboration but over time, it has enlarged and deepened by penetrating to political and social lives of the member countries. However, the presence of the EU has been tested since it was established, and the EU has overcome the crises. Since the beginning of the 2000s, the EU has experienced many crises such as constitutional crisis, economic crisis, migration crisis, Brexit and now coronavirus crisis. The concepts of "solidarity", "unity in diversity" and "free movement" which are components of values and achievements have also been tested and questioned. In this research, it is questioned how the coronavirus crisis affects the values and achievements of the EU. This crisis can be a war of existence for the EU itself and its values. It is obvious that the states will take a major blow in this crisis, but the EU will be facing with more. Even if it is not easy to see what will happen when the crisis is over it is clear that many things will change.
\end{abstract}

\footnotetext{
* Sorumlu yazar/Corresponding author.

e-posta: nerimanhocaogl@gmail.com
} 


\section{EXTENDED ABSTRACT}

Avrupa Birliği'nin (AB) kökenleri Avrupa Ekonomik Topluluğu'nu (AET) kuran Roma Antlaşması'na kadar gider. Süreç ekonomik alanda iş birliği ile başlamış ama zaman içerisinde farklı alanlarda da iş birliğine doğru evrilmiştir. 1957'den bu yana derinleşme ve genişlemeyle Topluluk bugünkü $\mathrm{AB}$ halini almıştır. Genişleme coğrafi olarak yayılmayı ifade ederken derinleşme daha fazla alanda iş birliğini ve ortaklaşmayı ifade etmektedir. Altı ülke ile kurulan AET genişlemelerle bugün yirmi yedi üyeli bir Birlik haline gelmiştir. İlk genişleme dalgası ile üye olan ülkelerden biri olan Birleşik Krallık, AB'den ayrılmayı isteyen ve bunu gerçekleştiren ilk ülke olmuştur.

$\mathrm{AB}$, tarihte pek çok kriz ile sınanmıştır. Ancak neredeyse son on yıllık zaman aralığında dört farklı kriz yaşanmıştır. İlk kriz ekonomik krizdir ve İspanya, İtalya ve Yunanistan krizden en fazla etkile ülkeler arasında yer alır. Ekonomik kriz sona ermeden 2015 yılında göç krizi ortaya çıkmıştır. Yine neredeyse aynı ülkeler krizden etkilenmişlerdir. Hatta Yunanistan üçüncü kurtarma paketinden faydalanırken kriz zirve noktasını da görmüştür. AB, göç krizinden sonra da AB'den ayrılmak isteyen Birleşik Krallık'ın neden olduğu Brexit krizi ile ilgilenmek durumunda kalmıştır. Her kriz ile AB'nin varlığı sorgulanmış ve dağılacağı yönünde ciddi söylemler ortaya çıkmıştır. Ancak Brexit krizinin yol açacağı tahmin edilen diğer ayrılıklar yaşanmamış ve Brexit bir domino etkisi göstermemiştir. AB'nin mücadele etmek durumunda kaldığı son kriz ise bütün dünyanın da mücadele ettiği koronavirüs krizidir.

$\mathrm{Bu}$ çalışma kapsamında AB'nin değerleri ve kazanımları olarak değerlendirilen dayanışma, birlik içinde çeşitlilik ve serbest dolaşım gibi kavramların bu son krizden nasıl etkilendiğini ve AB'nin bu krizle nasıl mücadele ettiğini incelenmektedir. Bunu ortaya koyabilmek için önce söz konusu kavramlar, bu kavramların nasıl ortaya çıtıkları ve dayanakları ortaya konulmuştur. Daha sonra AB'nin daha önce tecrübe ettiği ekonomik kriz, göç krizi ve Brexit açıklanmış, bu krizlerde söz konusu kavramların nasıl etkilendiğine yer verilmiştir. Son olarak koronavirüs krizinin $\mathrm{AB}$ değerleri ve kazanımları üzerindeki etkisi üzerinde durulmuştur.

Dayanışma kavramı pek çok $\mathrm{AB}$ metninde yer alan ve sıklıkla başvurulan $\mathrm{AB}$ değerlerinden biridir. Lizbon anlaşması ile de AB antlaşmaları içerisindeki yerini almıştır. Kavrama söz konusu Antlaşmada VII. Başlık olarak yer verilmiştir. 188r maddesi kapsamında da Birlik ve üye devletlerin bir devletin terörist bir saldırı ya da doğal veya insan kaynaklı bir felaketle karşı karşıya kalması durumunda AB'nin tüm araçlarını kullanmasını içermektedir (Eur-lex, 2007, p.100) ki bu da krizlerde AB'nin dayanışması anlamına gelmektedir. Diğer bir kavram olarak birlik içinde çeşitlilik de uzun yıllardır AB metinlerinde çeşitli şekillerde ifade edilmekle birlikte 2000li yıllar itibariyle AB'nin sloganı olarak kullanılmaya başlanmıştır ki farklılıklar içinde bütünlüğü, birliği yakalamayı ifade eder. Ayrıca AB'nin iç uyumunun sağlanmasında son derece önemlidir. Son olarak serbest dolaşım kavramı ve sınırlar konusuna değinilmektedir ki bu da AB'nin en büyük kazanımlarından biridir. Bu değerler ve kazanımlar krizlerden ciddi şekilde etkilenmişlerdir.

Bu çalışma ile görülmüştür ki koronavirüs krizinden Avrupa'da İtalya, İspanya ve Fransa gibi AB ülkeleri ile Birleşik Krallık'ı ciddi şekilde etkilenmişlerdir. Kriz ile mücadele kapsamında ülkeler virüsün yayılımını durdurabilmek için sınırları kapatmak, uçuşları durdurmak, dolaşımı ve kalabalık toplanmaları kısıtlamak ve okullara kapatmak gibi çeşitli tedbirler almışlardır. Bunun yanı sıra AB'den destek talebinde de bulunmuşlardır. Ancak AB söz konusu taleplere zamanında yanıt verememiştir. Bunun da çeşitli nedenleri bulunmaktadır. Öncelikle sağlık konusu AB'nin yetki alanı içerisine girmemektedir; bu alanda yetki ulus devletlere aittir. İkinci olarak da bütün dünya gibi AB'de bu krize hazırlıklı değildi. Üstelik bu kriz öncesinde üç kriz ile daha mücadele etmek zorunda kalmıştı. Aynı zamanda 2019 yılı AB için seçim yılıydı ve Komisyon ancak 2019'un sonunda göreve başlamıştı. Bu da bu denli büyük bir krizle mücadele etmesini zorlaştırmıştır. Bir süre sonra dayanışmayı sağlamak ve yardım çağrılarına cevap vermek amacıyla çeşitli mekanizmalar harekete geçirilmiştir ancak genel olarak AB'nin kriz ile mücadelede geç kaldığ 1 görülmektedir. Süreçte Birlik olarak hareket etmek de güçleşmiş, üye devletler kendi içlerine dönmüşlerdir. Schengen bölgesi içerisinde tekrardan sınır kontrolleri başlamış ve üye ülkeler arasında daha önceki krizlerde olduğu gibi bir ayrışma da olmuştur. Kuzey ülkeleri ile güney ülkeleri krizden aynı şekilde etkilenmemişler, mücadele konusunda ayrışmışlar ve güney ülkelerinin $\mathrm{AB}$ 'den istediklerini verme konusunda kuzey ülkeleri daha tutumlu olmayı tercih etmişlerdir. Bu en net şekilde bütçe konusunda görülmüştür. Ancak sonuç olarak bütçe konusunda ortak bir noktada buluşmayı başarmışlardır. Bu da çeşitlilik içerisinde birliğin geç de olsa bir ölçüde sağlanabildiğini göstermektedir. Koronavirüse ilişkin sayılara bakıldığında krizden nispeten daha az zarar gören Almanya, diğer krizlerde olduğu gibi Birlik içerisinde öncü konumda ve kriz yönetiminde söz sahibi olmuştur.

Sonuç olarak bu krizde, AB'nin dayanışma, çeşitlilik içerisinde birlik ve serbest dolaşım konularında sorunlar yaşadığı ve üye ülkelerin bu sorunlardan etkilendiği görülmektedir. Normal zamanlarda bu değer ve ilkelere sahip çımak kolay ancak kriz dönemlerinde bunun başarılmasının zor olduğu ve bu değerlerin kriz dönemlerinde olumsuz etkilendiği çok açıktır. $\mathrm{Bu}$ da $\mathrm{AB}$ 'nin geleceğinin sorgulanmasına neden olmaktadır. Ancak $\mathrm{AB}$ diğer krizleri atlattığı gibi bu krizi de değerleri zedelense de atlatacaktır. Tabii bu krizin AB'de birtakım değişikliklere de neden olacağı, AB'nin yetersizliklerinden hareketle yeni politikalar üreteceği ve sağlık alanında da iş birliğine gidebileceği öngörülmektedir. 


\section{Introduction}

The European Economic Community was established with the Treaty of Rome in 1957 by six European states, which are known as the founding states of the European Union (EU). Generally, the EU is defined as a sui generis organisation and it really is. It can also be described as a success story, after two world wars and many others, because it succeeded to bring and sustain peace in the continent. It did not just bring and sustain the peace, but it also provided stability and supported development and reconstruction of the continent and finally paved the way for its citizens. Prosperity came after a long and hard work.

The process of constructing EU and making it real for its citizens and the world was not easy. It took the EU many years to come to this point. They created common policies; constructed an identity; realized free movement of services, capitals, goods and persons eliminated borders; started to use common currency and many other developments. Over time, many concepts such as "unity in diversity", "solidarity", "burden sharing", "supranationalism", "free movement", "common good" and "common values", which are really at the heart of EU, came in sight. However, the process did not develop easily, the EU had to struggle with many crises especially in the 2000s. Some of these crises are constitutional crisis, economic crisis, migration crisis, Brexit and now coronavirus crisis. The EU was still struggling with migration crisis and Brexit before the coronavirus crisis arose. The crises, before the last one, damaged the EU and made it more fragile for the following crisis. Now, the member states of the supranational EU have been struggling with coronavirus crisis by themselves and this crisis endangers the constructed structure.

This research aimed to focus on the corner stones or let's say achievements of the EU such as solidarity, free movement and how they have been be affected by coronavirus crisis. It is also aimed to focus on the unity of the EU and its ability to combat against this enemy as a Union. With these aims, firstly, the EU and its cornerstones are explained and then the fragility of the EU is analysed. After giving the general framework before the outbreak of coronavirus crisis, it is focused on this crisis and its effects on the EU. Finally, the conclusion and the findings are stated.

\section{The EU and Its Cornerstones}

After the II. WW, a group of European states decided to come together and collaborate instead of fighting and destroying the continent. Collaboration was the best solution for that day as the construction of Europe and sustaining stability and developing was thought to be easier and faster than working on alone.

In this construction process, the first step was taken before the Treaty of Rome with the Treaty of Paris, which established European Coal and Steel Community. After this Treaty, the Treaty of Rome was signed, and it led to today's EU. But it was a step-by-step construction, which consists of widening and deepening. The process continued with both of these concepts. The first one, widening or in other words the enlargement, started in 1973 when the first enlargement realized with the membership of the UK, Ireland and Denmark and it took place till the last one; the membership of Croatia in 2013. But the process has not been completed yet; at least, it was not before the coronavirus crisis because there are still countries like Turkey, Serbia, Kosovo and Northern Macedonia, which are candidate countries. In 2013, the EU became a Union with 28 member states, but it changed with the Brexit process, which started in June 2016 with a referendum and became clearer with the withdrawal agreement. The agreement entered into force on 31 January 2020 at midnight, and from then on, till the end of December 2020, the transition period will continue to provide more time for adaptation (European Council, 2020). Now, the EU has twenty-seven member states. 
The notion of widening claims that the EU should get enlarged with the member states while the notion of deepening fights for more integration and ever closer union (Eur-lex, (n.d.)a). The deepening process is a little bit complicated as it is not a geographical widening like the enlargement, but it is a notion that the union should get closer and closer day by day with more integration. According to EU sources, economic and monetary union, the single currency and Euro are the best manifestations of this process (Eur-lex, (n.d.)a). However, there are many more constituents of both of these processes. In this research, it is going to be focused on some of these constituents of the EU because even the major manifestations did not pop up and the enlargements are not just outcomes instead both the deepening and widening processes move side by side supporting each other with harmony. They needed to be arose, matured, accepted, internalized, sustained and evolved.

Here, it is focused on unity in diversity in order to see if the member states succeeded to be united in this crisis. It is also focused on solidarity, which supports unity in diversity. Lastly, it is focused on the free movement, which is one of the most important achievements of the EU.

Unity in diversity, as the motto of the EU, is one of the concepts, which should be focused on. It first came into use in 2000 (Europa, (n.d.)) but it has a deeper history than the 2000s. It can be traced back to 1960s. Even though, it was not mentioned as unity in diversity in the first official documents, there were statements, which recall the motto. One of them can be seen in the final communiqué of the Hague Summit in 1969. In this document, it was noted that;

... a Europe composed of States which, in spite of their different national characteristics, are united in their essential interests, assured of its internal cohesion, true to its friendly relations with outside countries, conscious of the role it has to play in promoting the relaxation of international tension and the rapprochement among all peoples, and first and foremost among those of the entire European continent, is indispensable if a mainspring of development, progress and culture, world equilibrium and peace is to be preserved (CVCE, (n.d.)).

In this statement, both the differences and being united were expressed. It was noted that being united in the essential interests guarantee the internal cohesion of the Europe. This is an important emphasis at the early stages of the EU and as stated above later this emphasis took a more concrete form as the motto of the EU. According to the EU, it consists of two parts 'unity', which refers to coming together to work for peace and prosperity and 'diversity', which refers to the differences in the name of cultures, traditions and languages and it is accepted as a richness (Europa, (n.d.)). So, it can be said that the differences of the member states and citizens are united to sustain peace and increase prosperity. The concept was first aimed to sustain unity, integration, cohesion and peace and all these were related with different cultures, languages and identities. An example can be given from the Maastricht Treaty in which both culture and diversities were mentioned under Title IX as: "The Community shall contribute to the flowering of the cultures of the Member States, while respecting their national and regional diversity and at the same time bringing the common cultural heritage to the fore" (Eur-lex, 1992, p.24). Here, it is important to state that the motto is one of the values of the EU as it refers directly to its unity and it has been used as a motto since 2000. Within this research, it is also important to see how or whether the unity is sustained in the face of COVID-19 danger.

Another concept, which should be mentioned, is solidarity. It is also one of the concepts, which come to minds when the subject is EU. It is first mentioned in the Treaty of Rome and noted that it binds Europe and overseas countries (Eur-lex, 1957, p.2). In the Treaty, it was mentioned just once but in the Lisbon Treaty it was mentioned twenty-two times. Especially in Article 2 it was mentioned three times all are quite related with this research, as one of these mentions is that the EU "shall promote economic, social and territorial cohesion, and solidarity 
among Member States" (Eur-lex, 2007, p.11). Here, it is so clear that it is the duty of the EU to promote solidarity and cohesion among the member states, but it should not be just in treaties. It should be felt within the lives of the citizens of the EU. Solidarity between the member states was noted many more times in the Lisbon Treaty. A new Title VII and a new Article 188r were also added to the Treaty. The title is "Solidarity Clause" and according to Article 188r,

The Union and its Member States shall act jointly in a spirit of solidarity if a Member State is the object of a terrorist attack or the victim of a natural or man-made disaster. The Union shall mobilise all the instruments at its disposal, including the military resources made available by the Member States.. (Eurlex, 2007, p.100).

This Article is also crucial within the framework of this research as it underlined that the member states shall act together against threat and the Union shall mobilize its instruments against this threat. In today's situation, coronavirus is the common threat for the member states especially more for some of them.

Gerhard et. al. (2018) tried to find out how strong the European solidarity is, and they analysed solidarity of EU within different domains related to the crises which EU experienced in the last ten years. According to their findings, which are based on the surveys conducted in 13 EU countries, EU citizens display high level of solidarity with citizens of other EU countries in the domains of welfare state solidarity, territorial solidarity and fiscal solidarity but not the refugee solidarity, which challenges the EU solidarity, as there are different point of views among the citizens of western and southern Europe and the citizens of eastern Europe countries (Gerhard et. al., 2018, pp. 29-30). Over the last few years, solidarity has been often used with the concept of migration because the EU member states had problems in the management of migration crisis, which had its peak point in 2015 (Hocaoğlu Bahadır, 2019, p. 387). According to SOLIDUS and TransSOL, which are both EU projects, "solidarity is alive and active in Europe" but it is also "nuanced, conditional and often fragile" (EC, 2018, p. 3). Solidarity is also classified according to the actions conducted and there, it is stated that even though there are transnational actions, the actions are largely conducted at national level. It is also added that the actions at transnational level come across with constraints and barriers (EC, 2018, p.3). Therefore, it can be said that in some crisis solidarity is more alive than the others just like the migration crisis in which it is difficult to say that the solidarity was felt at the same level throughout the EU. According to another classification, solidarity can be national, member state and transnational solidarity: national solidarity refers to obligations among citizens and residents of member states, member state solidarity refers to obligations among member states and transnational solidarity refers to obligations among EU citizens (Sangiovanni, 2013, p. 217). This research focuses more on member state solidarity in order to reveal the success of the EU in combating COVID-19 within the EU. This research aims to analysis neither citizens solidarity nor transnational solidarity, it aims rather to show the solidarity among the member states which was and still is a matter of life or death especially for some of the member states.

The issue of borders is another subject related to the solidarity and the EU. Free movement and borderless Europe are some of the achievements of the EU. The concept of free movement in terms of goods, persons, capital and services is at the core of EU as it was first mentioned in the Treaty of Rome. In Article 3, the activities for the purpose of common market were stated and one of them was the abolition of obstacles to freedom of movement for persons, services and capital (EC, 1957, p. 4). The concept of free movement of persons have changed since its first introduction, it was underpinned with Maastricht Treaty and it was included and confirmed in Lisbon Treaty (Marzocchi, 2020, p. 1). Schengen aquis, which is closely related with free movement and has been formed, over time, consists of Schengen Agreement (1985), Schengen Convention (1990) and the related rules (EC, (n.d.)a). Today, there are twenty-two EU member states and four other states (Norway, Iceland, Switzerland and Liechtenstein) 
within the Schengen area. Some of the achievements of Schengen acquis are the abolition of internal borders, strengthening and harmonizing external borders and a common visa policy for third nationals (Marzocchi, 2020, p. 2). Angela Siebold (2017, pp. 995-996), analyses Schengen process with close relation to solidarity and she notes that the concept of solidarity has changed in time, as it was solidarity between the people of Europe at the beginning and then it became solidarity for both people and member states in the Maastricht Treaty and finally in 1997 and then on, it started to be noted as solidarity for states. Siebold (2017, p. 997) also notes that Schengen has been criticized for different reasons since the beginning and migration related problem is one of them. Even though there are some problems the European Commission ((n.d.)b) defines free movement of persons as "a fundamental right guaranteed by the EU to its citizens" and the citizens have right "to travel, work and live in any EU country without special formalities". Here, it should be noted that a Schengen country may reintroduce border control for a limited time and should inform other countries, the European Parliament and the Commission (EC, (n.d.)b).

In short, the EU has been changing and developing since the beginning in 1950s. It has some cornerstones, which are crucial for the presence of EU. Here, just the ones related with corona virus have been mentioned to be target oriented. Therefore, it is focused on just unity in diversity, solidarity and free movement of persons.

\section{The EU and the Recent Crises}

Since the beginning, the EU has experienced many crises and the presence of EU has been questioned many times. Even though this research does not focus on these crises it is important to note the recent crises in order to show the conditions before the coronavirus crisis. The crises, which are mentioned, are euro crisis, migration and Brexit. The EU was worn out because all of these crises, which broke out nearly in the last decade.

Financial crisis broke in the USA in 2007 and the effects of crisis felt in the EU, as well. According to Trevor Evans (2011, p. 100), because of Euro crisis the euro area economy suffered greater decline than the USA at the end of 2008. Peter A. Hall $(2018$, p. 9) notes that the EU economic activity as a whole regained its level before the global crisis nearly ten years after the start of the crisis. Some of the EU countries were able to manage the crisis but some of them had serious problems. According to Wallaschenk (2020, pp. 237-238), Greece, Ireland, Spain, Portugal and Cyprus were affected from the crisis while Germany manage to control it. Rescue packages were designed for these countries and they had bailout programmes. Ireland left the bailout programme in 2013, Portugal in 2014 and Greece benefitted longer than the other countries. This crisis can be seen as a challenge for the EU's solidarity, and staying together ability in a crisis. Here, it is important to see how the EU responded to the crisis: did it respond as a whole union or did each member state react individually? Another question is: did they stay together or were they separated? Looking from today, it can be claimed that they came over it, but it is important to look the process more closely. Wallaschenk (2020, p. 243) claims that "Euro crisis was a crisis of the common currency" and notes that "a new European financial architecture was established with the ESM and the Fiscal Compact". First of all, it should be noted that another mechanism was operational before European Stability Mechanism (ESM). It was the European Financial Mechanism; it still exists but not making new loans. These programmes helped the needed member states and keep the euro together. (ESM, (n.d.)). Even though help was provided during this crisis there were many discourses, which were dividing the Europe rather than uniting. Germany's policy was criticised from wide range of countries from France to crisis-ridden states and they asked for solidarity (Newman, 2015, p. 117). Germany affected less from the crisis with modest growth and less unemployment rates (Newman, 2015: 119). It played an important role and Newman (2019, p. 133) defines this role as a reluctant leader role that is "ever cautious and always circumscribed". However, there were 
grouping like northern and southern European countries. As noted above southern European countries affected more than the northern European countries. This led to growth of gap between the north countries evaluated as the core countries that are hard-working and frugal and southern countries as the periphery countries that are lazy and profligate within the Eurozone (Parsons and Matthijs, 2015, pp. 226-227). These discourses do not have positive effect over the crisis rather than carrying it to a different level where differences are not appreciated but criticized. Differences between the states became clear when there is a crisis and the only remedy is staying together, solidarity and burden sharing if it can be.

Migration crisis was another crisis, which hit Europe after the euro crisis. Or it should be said that it was still going on for some countries. Neriman Hocaoğlu Bahadır (2019, p. 387) giving numbers from Frontex notes that 2015 was the peak point of migration crisis as the illegal border crossing into Europe increased dramatically and Greece felt the pressure much more than many other member states, as it is on the routes of the migrants. Greece was one of the member states, which affected most from the euro crisis, as well and during its third economic adjustment programme (European Council, 2019) migration crisis exploded. Hungary and Italy were other two member states which affected most from the migration crisis (EC, (n.d.)c). Migration related issues has been on the agenda of EU for a long time but 2015 was the peak point when the illegal border crossings from Eastern Mediterranean route were eight hundred eighty-five thousand three hundred eighty-six (Frontex, n.d.). This huge number pushed the EU to take common action. Some of the measures taken by the EU were EU-Turkey Statement, a European Agenda on Migration which includes relocation plan, border controls and building walls and fences (Hocaoğlu Bahadır, 2019, p. 387).As it can be seen some of these measures were at state level some of them were at the EU level. Within this research relocation plan and border controls have special importance. The aim for designing relocation plan was to share responsibility and relocate a person from one EU member state to another to help most affected EU member states (Hungary, Greece and Italy) (EC, (n.d.)c). In an evaluation of the relocation mechanism in 2017, it was noted that it was a legally binding Council decision, but The Czech Republic, Hungary and Poland were mentioned as exceptions among the EU member states and infringement procedures launched for them (EC, 2017, pp. 1-2). These member states refused to respect to their obligations within the framework of relocation mechanism. Therefore, it can be said that in regard to migration crisis and relocation mechanism, solidarity and burden sharing within the EU did not give full satisfaction. This crisis was really important in terms of Schengen area, as well, as these people who entered EU illegally started to move within the EU borders. For some member states another measure was reintroducing border controls and for some other states building walls. However, it should be noted that border controls within the Schengen area could be temporary precautions as explained in Schengen Borders Control. According to it,

Where there is a serious threat to public policy or internal security, these countries may exceptionally reintroduce border controls at its internal borders for a period of no more than 30 days (possible to prolong under conditions established by the code) or for the foreseeable duration of the serious threat. (Eur-lex, (n.d.)b)

So, when it is needed border controls can be reintroduced and this right was used by the member states during the migration crisis.

The last crisis before COVID-19 was Brexit. In 2016, the UK voted to leave the EU. This was first in the EU history. Till 2016, countries were applying and when the accession negotiations with the candidate state were completed, the candidate state became a member of the EU. However, in 2016 the UK decided to ask to citizens whether they want to continue to be part of the EU or not. Citizens participated to the referendum and the results were a victory for the Euroscepticism. Even though the votes for leaving and remaining in the EU were close. 
$51.9 \%$ of the voters preferred to leave the EU while $48.1 \%$ of them wanted to remain in the EU ("Results: UK votes to," n.d.). After the referendum the Prime Minister of the UK changed for two times. First, Prime Minister Cameron resigned in 2016, then Theresa May became the Prime Minister and she also resigned in 2019 and then Boris Johnson became the Prime Minister. He managed to come to an end of the leaving process. The UK left the EU on 31 January 2020 and entered a transition period until the end of 2020. The transition period can be extended but an application to extend the process could be done before July 2020 (Barnes, 2020). First time, a member state voted to leave and left the EU. This led to revival of disintegration speeches and possible effects of Brexit among the Eurosceptic member states. For example, Vollaard (2018, pp. 241-247) discusses the possibility of Greece's withdrawal (Grexit), the Netherland, Italy, France, Cyprus and Slovenia's partial exit. But from today's point of view it can be said that Brexit did not create a domino effect.

In all these crises, Germany can be seen as the leading actor, which managed the crisis and guided on the decisions to be taken. However, according to Douglas Webber (2019, p. 213), in Brexit crisis Germany adopted the lowest profile in supporting Cameron in this process. Leonard Schutette (2019, p. 380) compares Euro and Schengen (migration) crises and he notes that while Euro crisis led to institutional and regulatory reforms, the Schengen (migration) crisis did not lead to meaningful reforms, as there were disagreements among the member states. These crises caused EU to weaken because of disagreements and discontent among the member states. In some of these crises, borders closed, and free movement became a little bit difficult. Burden sharing could not be possible because of Visegrad states point of views during the migration crisis. Moreover, solidarity is questioned in times of crises. And crises came one after another in the last decade. Finally, COVID-19 crisis appeared before the withdrawal of the UK completed.

\section{Coronavirus and Its Effects on the EU}

Coronavirus crisis is the last crisis in the EU, but it is not a crisis just going on in the EU; it is a crisis with which the whole world is tackling. It was first identified at the end of December 2019 in China (WHO, 2020). Since then, it has spread to the world and countries affected and are still being affected from this novel coronavirus.

The firs case was reported from France in Europe on 24 of January and then cases from Germany, Spain, the UK and Italy were reported. The first death was reported in Spain (Parkinson, 2020). The UK, Italy, Spain and France are the most affected countries in Europe according to the COVID-19 cases and death tolls. According to worldometer (n.d.), the UK has more than three hundred twenty-one thousand cases, Spain has more than three hundred eightyseven thousand, Italy has more than two hundred fifty-five thousand, Germany has more than two hundred twenty-nine thousand and France has more than two hundred twenty-five thousand cases. When it is looked at data related to deaths, the UK has more deaths than the EU members. Among the EU member states, Italy has more deaths than the other states. Italy, Spain and France are the member states, which have been affected more than the other member states, but the UK has more deaths than any other European country. These numbers should be evaluated proportionally with the population of the member states. Deaths/ $1 \mathrm{M}$ data can also be an important indicator for being able to take the general picture of the effects of COVID-19. According to worldometer's (n.d.) Deaths/ 1M data, Belgium comes to the top of the list and the Spain, UK, Italy, Sweden and France come respectively after Belgium. So, it can be said that looking just to the numbers of cases and death tolls may lead to miscalculation. It should also be noted that states make different numbers of tests and if a state does less tests it will probably have less cases. So, it is really difficult to evaluate the effect of coronavirus and besides, it may be misleading to try to evaluate it before it ends as the numbers and rates change day by day. Here, it should also be noted that it is not the main aim of these research to reveal 
the effects of COVID-19 on the member states but the responses of member states to see the solidarity, unity in diversity and free movement.

The member states of the EU and the UK responded in different ways to the COVID19 crisis. At first, the EU member states took independent precautions against the threat as the EU does not have a common health policy. Therefore, the states are free to determine how to react against this crisis. For example, even though Italy affected more than the other member states, it was the first to close the schools on 4 March and national lockdown came after a short time on 10 March. Full lockdown in France was on 17 March and in Spain on 14 March. Even though the Spain was second in declaring lockdown, it was criticised for being late as this lockdown came forty-three days after the first case (Parkinson, 2020). However, there is also a state like Sweden, which pursue a different policy. Sweden did not announce lockdown and schools and cafes have been open, they just banned large gatherings (BBC, 2020). There are more than eighty-five thousand cases and more than five thousand eight hundred deaths in Sweden (worldometer, (n.d.)). Even though its deaths are less than Germany, Sweden's population is less than eleven million, but Germany's is more than eighty-three million, (worldometer, (n.d.)). Therefore, it is obvious that mortality of coronavirus is more in Sweden than in Germany. According to Raynor de Best (2020), death rate of Sweden is $7.79 \%$ while Germany's death rate is $4.6 \%$. In the EU, Slovakia's rate $(1.68 \%)$ is the lowest and Belgium's rate is the highest (15.87\%). These rates were calculated according to July $1^{\text {st }}$ data and as Best notes that these rates may be misleading as countries has different policies in testing and asking to stay at home if they do not have severe symptoms and numbers are changing frequently. These all change the rates but not the different policies, which Sweden carries out. Here, it should also be noted that data is subject to change as the virus is still alive and spreading.

Even though, there are different policies in the fight against coronavirus, it should be noted that there are also common measures. For example, even if countries took common precautions at different times most of them took the same general measures: halting international flights, shutting down borders, closing schools and universities, banning indoor and outdoor gatherings with upper limits and lockdowns. But these measures were implemented in different times, as the virus was not spread to all over the world at the same time. Some states were at their peak point when some others were at the beginning. However, there were even different policies in timing of taking precautions. The UK may be a good example as they were late in implementing social distancing and other restrictions than their neighbours (Perrigo, 2020) and they affected worse than most of the EU member states.

In terms of this research, here, it will be focused on the responses of the EU in relation to unity in diversity, solidarity and mobility in fight against coronavirus to be in line with the previous parts. First of all, it should again be stated that the above-motioned measures were implemented in the EU member states as the threat is related with health sector, which is not common policy area for the EU and states are the main actors. Therefore, individual reactions can be evaluated normal. However, as noted above the motto of the EU is unity in diversity, solidarity is one of the cornerstones of the EU and mobility is one of the most effectively used rights of the citizens who have experienced free movement without borders for a long time.

Here, it should be noted once again that the virus did not spread with the same rate. Therefore, it would not be wrong to say neither the world nor the EU was able to response to virus quickly. At first, member states took own precautions and respond to it. Italy, France, Spain and the UK affected first and worse from the virus and their needs were alive in the news. Even if it leaves the EU as the UK wanted to become part of EU's early warning and response system (EWRS) (Rankin, 2020, the Guardian). For example, Italy reached to its peak point on $27^{\text {th }}$ of March, the UK on $10^{\text {th }}$ of April, Spain on the $2^{\text {nd }}$ of April and France nearly at the same time (worldometer, (n.d.)). Looking from the current point, it can be said that the EU managed 
the process, well, in general, and here, it will be focused on unity in diversity, solidarity and mobility. Before starting to evaluate it according to these concepts, it should be noted that the Commission was just set at the end of 2019 and COVID19 is its first crisis and it was just adapting to the process. It can be said that since the beginning of the crisis the coordination and managing the crisis have been improved and different tools have been introduced for combating COVID19 both within the EU and globally. The EU is not just fighting against the virus within its borders, it also has mechanisms and funds for neighbour countries for African countries and for all other countries in need such as Sudan, China, Congo, Jordan, Lebanon, Yemen, Palestine and Venezuela (EC, 2020a). Some of the EU tools to fight against the COVID19 are Civil Protection Mechanism, Corona Response Team, Emergency Response Coordination Centre (ERC), Team Europe approach, Coronavirus Global Response Initiative, and funds such as Emergency Trust Fund for Africa, REACT-EU, Solvency Support Instrument, European Fund for Sustainable Development. Here, it will be mentioned the responses of the EU slightly to be able to see how the EU manages this crisis.

After the outbreak of novel coronavirus the EU activated its Civil Protection Mechanism on January 28, 2020 and after a few days four hundred forty seven EU citizens brought from China with co-financing of this mechanism and later on $27^{\text {th }}$ of Mach it was noted that almost ten thousand people were repatriated to Europe through this mechanism and this number became over half million people on $17^{\text {th }}$ of April (EC, 2020a). Civil Protection Mechanism consists of EU member states, six participating states and the UK and it aims to strengthen cooperation to improve prevention, preparedness and responses to disaster (EC, 2020b). As it was noted above and took in the treaties of the EU, in times of natural or man-made disasters, it is the responsibility of the EU to mobilise all the instruments. Activating Civil Protection Mechanism is an example for how solidarity has been provided within the EU. Civil Protection Mechanism has been used many times during this crisis and it is also used for providing personnel equipment to the countries in need. Through this Mechanism, a team of European doctors and nurses also deployed to Italy to help the medical staff (EC, 2020a). These examples are good to see the solidarity within the EU. Member states also provided assistance individually to states in need. Corona Response team is another way of helping people in need in Europe by bringing together different strands of action and consists of three pillars; medical field, mobility and economy (EC, 2020c).

The EU has penetrated into many different sectors with its supports and guidelines some of these sectors are banks, health, transportation, agriculture, food, data protection, micro-small and start-up companies. The EU caught unprepared at the beginning of the crisis and it was criticised for not taking actions, reacting immediately and supporting the EU member states which called on help. For example, Italy was the first to call on the EU for medical equipment in the late February, but this call went unanswered and deliveries started at least three weeks later (Fischer, 2020). This is too late to answer a vital call during such a crisis related with health because the spread of virus was so quick, and patients and death numbers were increasing day by day. Many excuses can be found but the EU was late to respond this crisis. At the very beginning of the crisis, there was chaos. Health is not within the common policies of the EU and the Commission was not prepared for such a crisis and for that reason there was a coordination problem in the early days of the crisis. Some member states banned the transfer of medical supplies, some of them were hijacked, some of them were sold to higher prices to other countries and borders were closed. These were all opposed to solidarity, unity in diversity and free movement. The EU has been criticised about independent actions of the member states and there were points where criticism was justified. The European Parliament Survey (2020) was conducted in 21 member states at the end of April and at the beginning of May. Many questions were asked, and they were grouped in two. The first group questions were related 
with the EU's tools for such crises and the second group questions were related to solidarity in times of crises. In the first group, there were two questions. One of them is to what extend the participants are agree on the statement of "The EU should have more competences to deal with crises such as the Coronavirus pandemic" and the other question is "which you feel should be the European Union's top priorities in its response to Coronavirus" and they select up to three answers. According to first question, $69 \%$ of the interviewees agree that the EU should have more competences and $22 \%$ disagree. In terms of member states, Portugal takes the first place with $87 \%$ while Czech Republic is the last country with $43 \%$. The response for the second question shows that the EU's top priority in its response to coronavirus is to "ensure sufficient medical supplies (masks, gloves, tests etc.) are available for all EU Member States". In the second group, there is a question about the satisfaction of the interviewees with the solidarity between EU member states in this process. And according to the responds, 57\% of the interviewees are not satisfied while $34 \%$ of them are satisfied. Ireland is the most satisfied member state with 59\%, which is over the EU average, as well while Italy is the least satisfied with $16 \%$ and Spain is the second least satisfied member state with $21 \%$. So, it can be said that the member states, which affected most from the coronavirus pandemic in the EU, are the least satisfied. It is also clear that these member states did not feel the solidarity of the other member states. The belief in strengthening EU with more competences also can be interpreted, as the solidarity, which was expected, was not maintained. Therefore, it is difficult to say that what the EU have realized with mechanisms, funds and other tools were enough to feel the solidarity within the EU in terms of citizens views.

Nowadays, post corona economic recovery plan is one of the most discussed issue in the EU. Member States has not agreed on the financial support and its way of providing it. The Commission proposed it to be seven hundred fifty billion Euro which consists of five hundred billion euros as grants and two hundred fifty billion euros in loans, which will be backed by common debt among EU countries. However, member states have not agreed on the idea of borrowing together which was the issue in euro crisis, as well. In this crisis France and Germany agreed on borrowing but some of the member states (the Netherlands, Denmark, Austria and Sweden), which are named "frugal four" oppose to it ("EU Council Head Tries,", 2020). Even though the frugal four oppose to it in June, EU leaders agreed on the budget and recovery package on $21^{\text {st }}$ of July. According to this agreement, the grants will not be five hundred billion euros as proposed at first but instead three hundred ninety billion euros and the rest in loans. The frugal four "won some big concession in the core financial blueprint" but in the end, the deal can be seen as the success of Germany and France (Herszenhorn and Bayer, 2020). So, this deal is also about the solidarity and the criticism on solidarity in the EU, as it has been criticised for not taking actions in order to support the member states at the beginning of the crisis. This deal is also about the future of the EU, which is being questioned again with this crisis likewise the previous crisis. Even though all leaders are not equally satisfied with concessions, they managed to deal. This is a sign of solidarity and unity even if they have different views and priorities they manage to come to conclusion. The recovery plan and the budget are closely related with solidarity, but it is also important in terms of unity in the EU. Because unity in diversity is not just about the citizens but it is also about the member states, which have common points but also different components, points of views and priorities. They managed to stay united in budgetary issues even though the frugal four and some other were not looking with the same perspective. They found a way to compromise. However, this is the final point for now, at the beginning of the crisis it is difficult to note that member states are united in diversity. They prefer to become more introverted and focusing on their national borders instead of protecting their achievements within the EU in the last sixty years. 
Mobility or free movement is also one of the most effected issues from this crisis because it is a real and live achievement for the citizens as they were able to travel without borders. However, with the crisis the borders were closed and not just people, but medical supplies movement were also restricted. The border closures were not like the border closures in the migration crisis. Then, the threat for some of the member states were the people trying to migrate but now it is the movement of the citizens as the mobility itself is dangerous because it provides the virus opportunity to find place to survive. So, the best measure was evaluated as not being mobile not just among the member states but sometimes among the cities. On 17 March 2020, the member states agreed on decisions about the external borders and travel restrictions for a period (EC, (n.d.)e). However, there were also restrictions within the EU, member states reinstalled border controls. Within the context of Schengen Border Code, member states have the right to reintroduce temporary border control at the internal borders in times of a serious threat as last resort, which is a COVID-19 pandemic now (EC Migration and Home Affairs, (n.d.)). This action is quite challenging for one of the EU achievements: free movement. Border issue and free movement within the EU borders was also the issue in migration crisis as mentioned above and then some of the borders were closed. In this crisis, borders between some member states were closed again. For example, in the context of COVID-19, Denmark (till 12 November), Finland (till 25 August), Lithuania (till 15 August) and Norway (till 13 August) reintroduced border controls generally within all internal borders but Finland stated the countries, which are Spain, Luxembourg, Portugal, Poland, France, Sweden, Czechia, Austria, Slovenia, and Switzerland. There are also border control reintroductions in context different from COVID-19 pandemics (EC Migration and Home Affairs, (n.d.)). Border controls were more at the beginning of the pandemic but with the normalisation process the list has been shortened. Since 2006, border controls have been reintroduced two hundred twenty three times and in 2020 they have been reintroduced one hundred and one times and Austria was the first member state which reintroduced border control with Italy on 11 March 2020 because of coronavirus (EC, (n.d.)d). The border issue is a little bit complex in terms of unity, as well, as member states are not acting together. They all have different timetables for opening or closing borders, different lists for which countries the borders will be opened or closed and different measures and rules in letting people to their countries. This is a live list, which is changing in short terms and updated according to the changes.

\section{Conclusions}

The EU has been tackling with crises since the Eurozone crisis. Crises came one after one. The previous crises, which are economic crisis, migration and Brexit can be evaluated as more internal crises but COVID-19 is a universal crisis. Even if all the countries are not affected same, nearly all of the countries felt the threat. Neither the world, nor the EU was prepared for this crisis. They could not see the threat beforehand and could not respond properly at first. It took time the EU to react to the virus.

It is difficult to note that the EU acted together at the beginning of the crisis. Each member state took its own measures and they reacted individually. The first measures were closing borders, halting flights, restricting mobility and gatherings and suspending schools. After a while lockdowns came. Member states followed inward policies and they once again took the control of their borders. They did not follow common policies, as the health sector is not one of the common policies of the EU. Member states have a say and they are the decisionmakers in health-related matters. Therefore, they followed different methods in line with their countries needs and priorities in combating the epidemic. Some of them asked the EU for help but the EU could not react immediately, and it was a little bit late when the EU was ready to 
answer the calls. After a while the EU activated its mechanisms not just for its member states but also for other states that needed vital help.

Different reasons can be put forward for the EU's inability to respond to the crisis immediately, but the first is that no country was ready for the crisis. The second reason may be the nature of the virus as it spread so fast and easily in a globalised world where mobility is intense. However, there are also reasons for the EU itself such as it has experienced many crises in the last decade. Moreover, it is difficult to say that the EU has overcome the last crises when the corona crisis occurred. There were elections in the EU 2019 and the Commission just took its office at the end of 2019. Therefore, it took time to get organised and manage the crisis. But the most important reason as mentioned above can be the EU does not have decision-making power in the field of health. The member states are the main actors. They made decisions but they also called for help, as the spread of crisis in some of the EU member states such as Italy, Spain and France were so fast. These member states affected most than many other member states. Germany affected less when compared to these states and took a leading role in managing the crisis just like in the previous crises.

In terms of EU values and achievements such as solidarity, unity in diversity and free movement, this crisis is a test for the EU's cohesion and existence. Its existence was questioned at the beginning of the crisis just like in all other crises. In terms of these concepts, it is difficult to note that the EU is successful in managing the crisis as they could not react together but instead, they closed inward. Solidarity could not be seen at first sight and member states were late to help each other. It was difficult to see a united EU in diversity. Moreover, differences were more apparent and member states became less tolerant during the crises. It should also be noted that member states were separated as northern states and southern states as in the previous crises. However, they succeeded to come to conclusion in budget talks and recovery package. This is a good sign for solidarity and unity in the EU as they have different views and priorities, but they manage to make a deal. Even if, the EU was late in managing the crisis at the beginning, after a while it found a way to stay together. Borders and free movement are also important in this crisis as free movement is one of the rights of the EU citizens and one of the important achievements of the EU. In this crisis, member states reintroduce border controls with neighbours and they updated their border controls according to the changes in the process. With the normalising process most of the borders opened. Here, it should also be noted that according to the survey conducted for the Parliament the member states, which affected most from the coronavirus pandemic in the EU, are the least satisfied with the EU's solidarity.

In the future, the EU may develop policies to be ready for such health-related crises as they initiate mechanisms and provide funds to combat against coronavirus. The EU is a dynamic Union, it is not stable, it will learn from its inabilities just like it learnt from the previous crises. In short, the EU will survive as Vollaard (2018, s. 250) notes "The EU will yet survive also a series of crises due to the remaining resourceful member states, albeit under one important condition: that there are not any viable national or international alternatives to the EU.".

\section{References}

Barnes, P. (2020, February 5). Brexit: What happens now?. BBC. Retrieved 15 May 2020 from: https://www.bbc.com.

CVCE. (n.d.). Final communiqué of the hague summit (2 December 1969). Retrieved 23 April 2020 from: http://www.cvce.eu/content/publication/1997/10/13/33078789-8030-49c8b4e0-15d053834507/publishable_en.pdf.

De Best, R. (2020). Coronavirus (COVID-19) death rate in countries with confirmed deaths and over 1,000 reported cases as of July 1, 2020, by country. Statista. Retrieved 15 July 
2020 from: https://www.statista.com/statistics/1105914/coronavirus-death-ratesworldwide/.

EC Migration and Home Affairs. (n.d.). Retrieved 15 July 2020 from: Temporary reintroduction of border control, https://ec.europa.eu/home-affairs/what-wedo/policies/borders-and-visas/schengen/reintroduction-border-control_en.

EU Council head tries to win over 'frugal four' on budget. (2020, July 10). The New York Times. Retrieved 15 July from: https://www.nytimes.com.

Eur-lex. (1957). The treaty of Rome. Retrieved 5 June 2020 from: https://ec.europa.eu/archives/emu_history/documents/treaties/rometreaty2.pdf.

Eur-lex. (1992). Treaty on European Union, Retrieved 5 June 2020 from: http://eurlex.europa.eu/legal-content/EN/TXT/PDF/?uri=CELEX:11992M/TXT\&from=EN.

Eur-lex. (2007). Treaty of Lisbon. Retrieved 4 June 2020 from: https://eur-lex.europa.eu/legalcontent/EN/TXT/PDF/?uri=OJ:C:2007:306:FULL\&from=EN.

Eur-lex. (n.d.)a. Glossary of summaries: Widening and deepening. Retrieved 27 March 2020 from:

https://eur-

lex.europa.eu/summary/glossary/deepening_european_integration.html.

Eur-lex. (n.d.)b. Schengen borders code retrieved 9 July from: https://eur-lex.europa.eu/legalcontent/EN/TXT/HTML/?uri=LEGISSUM:114514\&from=EN.

Europa. (n.d.). The EU motto. Retrieved 7 April 2020 from: https://europa.eu/europeanunion/about-eu/symbols/motto_en.

European Commission (EC) (2018). Solidarity in Europe alive and active, publication office of the EU. Retrieved 5 June 2020 from: https://op.europa.eu/en/publication-detail//publication/9adba623-d66f-11e8-9424-01aa75ed71a1.

European Commission (EC). (2020)a. Timeline of EU action, retrieved 1 June 2020 from https://ec.europa.eu/info/live-work-travel-eu/health/coronavirus-response/timeline-euaction_en.

European Commission (EC). (2020)b. EU civil protection mechanism. Retrieved 5 June 2020 from: https://ec.europa.eu/echo/what/civil-protection/mechanism_en.

European Commission (EC). (n.d.)a. Schengen agreement and convention. Retrieved 20 July 2020 from: https://ec.europa.eu/home-affairs/e-library/glossary/schengen-agreementconvention_en.

European Commission (EC). (n.d.)b. Schengen area. Retrieved 5 June 2020 from: https://ec.europa.eu/home-affairs/what-we-do/policies/borders-and-visas/schengen_en.

European Commission (EC). (n.d.)c. European solidarity: Refugee relocation system, retrieved 5 June 2020 from: https://ec.europa.eu/home-affairs/sites/homeaffairs/files/what-wedo/policies/european-agenda-migration/backgroundinformation/docs/2_eu_solidarity_a_refugee_relocation_system_en.pdf.

European Commission (EC). (n.d.)d. Member States' notifications of the temporary reintroduction of border control at internal borders pursuant to Article 25 and 28 et seg. of the Schengen Borders Code. Retrieved 22 August 2020 from: https://ec.europa.eu/home-affairs/sites/homeaffairs/files/what-we-do/policies/bordersand-visas/schengen/reintroduction-border-control/docs/ms_notifications__reintroduction_of_border_control_en.pdf. 
European Commission (EC). (n.d)e. Travel and Transportation during the coronavirus pandemic. Retrieved 15 July 2020 from: https://ec.europa.eu/info/live-work-travel$\mathrm{eu} / \mathrm{health} /$ coronavirus-response/travel-and-transportation-during-coronaviruspandemic_en.

European Commission (EU). (2020)c. European Commission's Coronavirus Response Team. Retrieved 12 July 2020 from: https://ec.europa.eu/info/live-work-travel$\mathrm{eu} /$ health/coronavirus-response/european-commissions-action-coronavirus_en.

European Council. (2019). Greece: the third economic adjustment programme. Retrieved 21 August 2020 from: https://www.consilium.europa.eu/en/policies/financial-assistanceeurozone-members/greece-programme/.

European Council. (2020, January 30). Brexit: Council adopts decision to conclude the withdrawal agreement [Press release]. Retrieved 6 April 2020 from: https://www.consilium.europa.eu/en/press/press-releases/2020/01/30/brexit-counciladopts-decision-to-conclude-the-withdrawal-agreement/.

European Parliament (EP). (2020). Public opinion in the EU in time of Coronavirus crisis. $\begin{array}{lllll}\text { Retrieved } & 12 & \text { July } & 2020 & \text { from }\end{array}$ https:/www.europarl.europa.eu/resources/library/media/20200527RES79925/2020052 7RES79925.pdf.

European Stability Mechanism (ESM). (n.d.), History. Retrieved 12 July 2020 from: https://www.esm.europa.eu/about-us/history.

Evans, T. (2011). The crisis in the euro area. International Journal of Labour Research, 3(1), 97-113.

Frontex. (n.d.). Migratory routes. Retrieved 15 July 2020 from: https://frontex.europa.eu/alongeu-borders/migratory-routes/eastern-mediterranean-route/.

Gerhards, J., Lengfeld, H., Ignácz, Z.S., Kley, F.K. \& Priem, M. (2018). How strong is European solidarity? BSSE Working Paper, No. 37.

Hall, P.A. (2018). Varieties of capitalism in light of the euro crisis. Journal of European Public Policy, 25(1), 7-30.

Hocaoğlu Bahadır, N. (2019). Responses of the visegrad states to the migration crisis and the European identity. In Y. Bayar (Ed.), Handbook of Research on Social and Economic Development in the European Union, 381-399: IGI Global.

Marzocchi, O. (2020). Free movement of persons, fact sheets on the European Union, European $\begin{array}{lllll}\text { Parliament. } & \text { Retrieved } 20 & \text { June } & 2020 \text { from: }\end{array}$ https://www.europarl.europa.eu/ftu/pdf/en/FTU_4.1.3.pdf.

Newman, A. (2015). The reluctant leader Germany's euro experience and the long shadow of reunification. In M. Matthijs and M. Blyth (Ed), The Future of the Euro, 117-135: New York: Oxford University Press.

Parkinson, G. (2020, March 24). COVID-19 timeline betrays European countries' different responses. Retrieved 2 July 2020 from: https://newseu.cgtn.com.

Parsons, C. \& Matthijs, M. (2015). European integration past, present, and future moving forward through crisis? In M. Matthijs and M. Blyth (Ed), The Future of the Euro, 210232: New York: Oxford University Press.

Perrigo, B. (2020, April 17). Coronavirus could hit the U.K. harder than any other European country. Here's What Went Wrong, Time. Retrieved 3 July 2020 from: 
https://time.com.

Rankin, J. (2020, May 2). UK seeks access to EU health cooperation in the light of coronavirus, The Guardian. Retrieved 3 July 2020 from: https://www.theguardian.com.

Results: UK votes to leave the EU. (n.d.). BBC. Retrieved 3 June 2020 from: https://www.bbc.com.

Sangiovanni, A. (2013). Solidarity in the European Union. Oxford Journal of Legal Studies, $33(2), 213-241$.

Schuette, L. (2019). Comparing the politicisation of EU integration during the Euro and Schengen Crises. Journal of Contemporary European Research, 15(4), 380-400.

Siebold, A. (2017). Open borders as an act of solidarity among peoples, between states or with migrants: changing applications of solidarity within the Schengen process. European Review of History: Revenue europeenne d'histoire, 24(6), 991-1006.

Vollaard, H. (2018). European disintegration a search for explanations. London: Macmillan.

Wallascheek, S. (2020). Framing solidarity in the euro crisis: A comparison of the German and Irish media discourses. New Political Economy, 25(2), 231-247.

Webber, D. (2019). European disintegration? The politics of Crisis in the European Union. London: Red Globe Press.

WHO (2020, April 27). Archived: WHO timeline COVID-19. Retrieved 2 July 2020 from: https://www.who.int/news-room/detail/27-04-2020-who-timeline---covid19?gclid=CjwKCAjwi_b3BRAGEiwAemPNUzdmm8gFxn0U6ViggVK6LatqnVT1lb 6UBT3EeOno8LDa04QnMvh5dxoCohwQAvD_BwE.

Worldometer (n.d.). COVID-19 Coronavirus pandemic. Retrieved 20 August 2020 from: https://www.worldometers.info/coronavirus/. 